\title{
Effect of Fermented used rice as a functional feed on biochemical and haematological parameters, microbial population, internal organ weight and performance of broilers
}

\author{
T. Yudiarti, E. Widiastuti, H. I. Wahyuni and Y.B. Pramono \\ Faculty of Animal and Agricultural Sciences. Diponegoro University, \\ Tembalang Campus, Semarang, 50275 - Indonesia \\ Corresponding E-mail: tyudiarti@yahoo.co.id
}

Received July 20, 2020; Accepted August 19, 2020

\begin{abstract}
ABSTRAK
Penelitian bertujuan untuk mengevaluasi pengaruh pemberian nasi aking yang difermentasi menggunakan Chrysonillia crassa sebagai pakan fungsional terhadap parameter biokimia dan hematologi, populasi mikroba, bobot relatif organ internal, dan performa ayam broiler. Penelitian menggunakan ayam sebanyak 150 ekor umur satu hari (DOC) (unsexed) dengan bobot rata-rata 48,30 \pm 4,13g. Hari ke 1 sampai 7,ayam diberi pakan komersial. Pada hari ke-8 dan seterusnya,ayam didistribusikan secara acak masing-masing 50 ekor ke salah satu dari tiga perlakuan. Ayam diberi pakan yang diformulasikan sebagai pakan fungsional yaitu berisi nasi aking yang difermentasi. Air minum diberikan secara ad libitum. Penelitian menggunaan rancangan acak lengkap dengan tiga perlakuan yaitu T0 (pakan tanpa pakan fungsional), T1 (pakan berisi 5\% pakan fungsional), dan T2 (pakan berisi 10\% pakan fungsional). Ayam yang diberi nasi aking fermentasi mampu meningkatkan status kolesterol, high density lipoprotein, mean corpuscular hemoglobin concentration, populasi bakteri asam laktat, berat jantung dan menurunkan mean corpuscular volume, populasi $E$ coli, berat jejunum, serta tidak mempengaruhi pertambahan bobot badan,feed conversion ratio dan konsumsi pakan. Sebagai kesimpulan penelitian ini adalah penggunaan pakan nasi aking fermentasi mampu meningkatkan kondisi fisiologis dan populasi bakteri usus serta tidak berpengaruh buruk pada pertumbuhan broiler.

Kata kunci : pakan fungsional, fermentasi,parameter fisiologis,populasi mikroba,organ internal, performans, broiler
\end{abstract}

\begin{abstract}
The study aimed to evaluate effect of the used rice fermented using Chrysonillia crassa as a functional feed on biochemical and haematological parameters, microbial populations, internal organ weight and performance of broilers. The study used one hundred and fifty unsexed one-day-old chicks with average body weight of $48.30 \pm 4.13 \mathrm{~g}$. At day 1 to 7 , the chicks were given commercial feed. On day 8 onward, the chickens were randomized distributed to one of three experimental diets of 50 chicks each. The chicks were given formulated diet containing fermented used rice based-functional feed (FF). Drinking water was provided ad libitum. The study used completely randomized design with three experimental diets : T0 (diet without FF), T1 (diet contained 5\% FF), and T2 (diet contained 10\% FF). The chicken fed the used rice fermented increased in cholesterol, high density lipoprotein status, mean corpuscular haemoglobin concentration, lactic acid bacteria, heart weight. and decreased in mean corpuscular volume, E.coli, jejunum weight, but no affect on body weight gain, feed convertion ratio and feed comsumption. In conclusion that the fermented used rice improved the physiological
\end{abstract}


conditions, intestinal bacterial population and had no detrimental effect on performance of broiler.

Keywords: functional feed,fermentation, physiological parameters, microbial population, internal organ,performance, broiler

\section{INTRODUCTION}

Since 2018, the Indonesian government has banned the use of antibiotics growth promoter (AGP) and also restricted the chemical-based antioxidants as the substances to trigger the growth and maintain health of livestock. This is certainly a problem for farmers, because they always use both ingredients to increase productivity and maintain animal health. Besides that problem, farmers are also faced with expensive broiler feed ingredients such as yellow corn and soybean meal. The high price is because most of the stuffs are still imported and this will have an impact on production costs. Such conditions, when occur continuously, are not profitable for farmers. In response to this problem, the alternatives for AGPs and synthetic antioxidants must be sought as well as alternative feed sources that can replace or reduce the proportion of conventional feed ingredients for chicken rations. The use of functional feed ingredients seemed to deal with the above problems as previously suggested by Sugiharto et al. (2018).

Currently, functional feed is not yet widely used in poultry farms. Sugiharto et al. (2018) defined functional feed as the whole feed, fortified, enriched or enhanced feed that have potentially health effects in addition to the basic nutrition. Physically, conventional feed and functional feed have similar appearance, but functional feed has the advantage of providing components to support health and growth (Cencic and Chingwaru, 2010). Functional feed also has the potential to improve the microecology of the broiler digestive tract, health performance and production (Sugiharto and Rajitkar, 2019). Among the examples of functional feeds for poultry is fermented feed (Sugiharto et al., 2018).

Currently the used rice is abundantly available, but not yet used as ordinary feed ingredients due to its low nutritional value. Fermentation has traditionally been applied to improve the nutritional characteristics of stuffs (Sugiharto and Ranjitkar, 2019). Formerly, Yudiarti et al. (2019; 2020) reported that fermentation using Chrysonillia crassa improved nutritional characteristics and antioxidant properties of the used rice and some selected agroindustrial by-products. The fungus was actually isolated from ileum of the Indonesian native chicken and has been shown to possess probiotic activities in vitro and in vivo (Yudiarti et al., 2012; Sugiharto et al., 2017). Being used as fermentation starter, the fungus Chrysonillia crassa was also able to ferment the used rice and improve the nutritional quality, antioxidants and antimicrobial activity of the product. Before it is fermented by the fungus, its nutritional content, antioxidant activity and antimicrobial activity are low (Yudiarti et al., 2019). On this basis, the fungus Chrysonillia crassa was therefore could be used to produce the used rice-based functional feed ingredients to substitute the role of AGP and chemical-based antioxidants as well as to reduce the proportion of energy-rich feed ingredients such as yellow corn. The present study aimed to evaluate effect of the used rice fermented using the fungus Chrysonillia crassa as a functional feed on biochemical and hematological parameters, microbial population, internal organ weight, and performance of broilers.

\section{MATERIALS AND METHODS}

One hundred and fifty unsexed one-day-old chicks with average body weight of $48.30 \pm 4.13 \mathrm{~g}$ were used in the current study. At day 1 to 7, the chicks were given commercial feed. On day 8 onward, the chicks (body weight of $124.48 \pm$ $15.97 \mathrm{~g})$ were randomly distributed to one of three experimental diets of 50 chicks each $(5$ replicates of 10 chicks). The chicks were given formulated diets containing fermented used rice based-functional feed (FF). The composition of basal diet is presented in Table 1. Drinking water was provided ad libitum. The study used completely randomized design with three experimental diets included T0 (diet without FF), $\mathrm{T} 1$ (diet contained 5\% FF), and T2 (diet contained $10 \% \mathrm{FF}$ ). The vaccine was given to all chicks, i.e., Newcastle diseases-infectious bursal (ND-IB) vaccines on day 4 through eye drops and day 18 through drinking water. The birds were reared in colony cages $1 \times 1 \mathrm{~m}$ equipped with manual feeder and drinker. Light was provided throughout the 
Table 1. Composition of Basal Diet Added with Fermented Feed

\begin{tabular}{|c|c|c|c|c|c|c|}
\hline \multirow{2}{*}{ Items $(\%)$} & \multicolumn{3}{|c|}{ Starter } & \multicolumn{3}{|c|}{ Finisher } \\
\hline & T0 & $\mathrm{T} 1$ & $\mathrm{~T} 2$ & T0 & $\mathrm{T} 1$ & $\mathrm{~T} 2$ \\
\hline Meat bone meal & 4.7 & 4.7 & 4.7 & 2.35 & 2.35 & 2.35 \\
\hline Corn & 54.8 & 50.8 & 47 & 58.5 & 54.55 & 50.66 \\
\hline Soybean Oil & 1.55 & 1.25 & 0.8 & 3.25 & 2.9 & 2.5 \\
\hline Soybean meal & 35.7 & 35 & 34.25 & 32.65 & 31.95 & 31.24 \\
\hline DL-methionine & 0.3 & 0.3 & 0.3 & 0.3 & 0.3 & 0.3 \\
\hline L-Lysine & 0.2 & 0.2 & 0.2 & 0.2 & 0.2 & 0.2 \\
\hline Limestone & 0.5 & 0.5 & 0.5 & 0.5 & 0.5 & 0.5 \\
\hline Dicalcium phosphate & 1.5 & 1.5 & 1.5 & 1.5 & 1.5 & 1.5 \\
\hline Premix $^{1}$ & 0.5 & 0.5 & 0.5 & 0.5 & 0.5 & 0.5 \\
\hline $\mathrm{NaCl}$ & 0.25 & 0.25 & 0.25 & 0.25 & 0.25 & 0.25 \\
\hline Fermented the used rice & 0 & 5 & 10 & 0 & 5 & 10 \\
\hline \multicolumn{7}{|l|}{ Nutrient content } \\
\hline Crude protein $(\%)$ & 22.04 & 22.04 & 22.03 & 20.04 & 20.04 & 20.04 \\
\hline Crude fiber (\%) & 5.59 & 5.32 & 5.07 & 5.54 & 5.28 & 5.02 \\
\hline $\operatorname{ME}(\mathrm{kkal} / \mathrm{kg})^{2)}$ & 2901 & 2907 & 2905 & 3063 & 3066 & 3066 \\
\hline
\end{tabular}

${ }^{1}$ Premix contained (per $\mathrm{kg}$ of diet) of vitamin A 7,750 IU, vitamin D3 1,550 IU, vitamin E $1.88 \mathrm{mg}$, vitamin B1 $1.25 \mathrm{mg}$, vitamin B2 $3.13 \mathrm{mg}$, vitamin B6 $1.88 \mathrm{mg}$, vitamin B12 $0.01 \mathrm{mg}$, vitamin C $25 \mathrm{mg}$, folic acid $1.50 \mathrm{mg}$, Ca-d-pantothenate $7.5 \mathrm{mg}$, niacin $1.88 \mathrm{mg}$, biotin $0.13 \mathrm{mg}$, BHT $25 \mathrm{mg}$, Co $0.20 \mathrm{mg}$, Cu $4.35 \mathrm{mg}$, Fe $54 \mathrm{mg}$, I $0.45 \mathrm{mg}$, Mn $130 \mathrm{mg}$, Zn $86.5 \mathrm{mg}$, Se $0.25 \mathrm{mg}$, L-lysine $80 \mathrm{mg}$, Choline chloride $500 \mathrm{mg}$, DLmethionine $900 \mathrm{mg}, \mathrm{CaCO} 3641.5 \mathrm{mg}$, DCP $1500 \mathrm{mg}$

${ }^{2}$ Metabolizable energy was calculated according to formula (Bolton, 1967) as follows : 40.81 [0.87 crude protein +2.25 crude fat + nitrogen-free extract) +2.5 ]

T0: chicks receiving basal diet without FF, $\mathrm{T} 1$ : chicks rcceiving basal diet contained 5\% FF, T2 : chicks rcceiving basal diet contained $10 \% \mathrm{FF}$

day.

Sample collection was conducted at day 42 of experiment. For the complete blood counts and serum biochemical analyses, blood from the chicken's wing veins was placed in ethylenediamine-tetraacetic acid (EDTA)-containing vacutainers and vacutainers without anticoagulant, respectively. The blood in the latter vacutainers was coagulated at room temperature and centrifuged at $5,000 \mathrm{rpm}$ for 15 minutes to produce serum. The serum was frozen until analyses. The same chicken that blood sampled were slaughtered, de-feathered and the abdominal contents (internal organs) were then removed and weighed. For counting a full blood cells, the measurement using a hematology analyzer (Prima
Fully-auto Hematology Analyzer, PT. Prima Alkesindo Nusantara, Jakarta, Indonesia) was conducted according to the manufacturer's instructions.

The determinations of the levels of total triglyceride, total cholesterol, high-density lipoprotein, and low-density lipoprotein cholesterol were conducted according to the enzymatic colorimetric/color method. For determining the total protein and albumin in serum, the spectrophotometric/photometric tests was applied. The biochemical analyses in serum were conducted using kits (DiaSys Diagnostic System GmbH, Holzheim, Germany) according to the manufacturer's instructions.

The enumerations of coliform bacteria 
conducted on MacConkey agar (Merck KGaA) following aerobic incubation at $38{ }^{\circ} \mathrm{C}$ for $24 \mathrm{~h}$ as red colonies. Lactic acid bacteria (LAB) were enumerated on de Man, Rogosa and Sharpe (MRS; Merck KGaA) agar after anaerobic incubation at $38{ }^{\circ} \mathrm{C}$ for $48 \mathrm{~h}$. The data obtained were analysed according to analysis of variance (Steel and Torrie, 1997) and followed by Duncan's multiple range test to assess the difference between mean values $(\mathrm{P}<0.05)$.

\section{RESULTS}

\section{Biochemical Parameters}

Diet containing $10 \% \mathrm{FF}$ increased $(\mathrm{P}<0.05)$ total cholesterol and HDL levels of chickens. The dietary treatments did not affect $(\mathrm{P}>0.05)$ LDL, triglycerides, SGOT, SGPT, abdominal fat, albumin, total protein, uric acid and creatinine of the chickens (Table 2).

\section{Hematological Parameters}

Diet containing 5\% FF decreased ( $\mathrm{P}<5 \%$ ) on Mean corpucular volume (MCV) and increased on Mean corpuscular haemoglobim concentration (MCHC) of broiler chickens. The dietary treatments had no effect on leucocyte, erithrocyte, hemoglobin, hematocrit, platelets, lymphocyte, neutrophils, and $\mathrm{MCH}$ of the chickens (Table 3).

\section{Intestinal Microbial Population}

Diet containing $10 \%$ FF significantly decreased $(\mathrm{P}<5 \%)$ Escherichia coli and increased lactic acid bacteria (LAB) colonies in caecum of broiler. However, the dietary treatments had no effect $(\mathrm{P}>0.05)$ on the number of $E$. coli and BAL colonies in ileum (Table 4).

\section{Internal Organs Weight}

Diet containing $10 \%$ FF increased $(\mathrm{P}<0.05)$ the relative weight of heart and decreased jejunum of chicks. The dietary treatments had no effect $(\mathrm{P}>0.05)$ on the weight of liver, proventriculus, gizzard, pancreas, spleen, thymus, bursa fabricius, duodenum, ileum and cacum of the chickens Table 5).

\section{Body Weight Gain, FCR and Feed Comsumption}

Diet containing $10 \% \mathrm{FF}$ did not affect on the body weight gain (BWG), FCR and feed

Table 2. Biochemical Parameters of the Chicken Fed Fermented the Used Rice

\begin{tabular}{lccccc}
\hline \multicolumn{1}{c}{ Parameter } & T0 & T1 & T2 \\
\hline Total cholesterol & $104 \quad \pm 10.4^{\mathrm{b}}$ & 130 & $\pm 12.1^{\mathrm{a}}$ & $125 \quad \pm 27.6^{\mathrm{ab}}$ \\
HDL & $88.2 \pm 8.79^{\mathrm{b}}$ & 127 & $\pm 27.9^{\mathrm{a}}$ & $127 \quad \pm 27.1^{\mathrm{a}}$ \\
LDL & $6.57 \pm 9.08$ & $4.60 \pm 7.80$ & $7.26 \pm 14.1$ \\
Triglycerides & $80.4 \pm 21.6$ & $71.4 \pm 33.6$ & $59.1 \pm 20.4$ \\
SGOT & $263 \pm 24.8$ & 257 & \pm 45.9 & $264 \quad \pm 69.9$ \\
SGPT & $2.41 \pm 0.78$ & $2.28 \pm 0.55$ & $1.76 \pm 0.50$ \\
Abdominal fat & $28.6 \pm 8.08$ & $28.6 \pm 11.6$ & $24.9 \pm 12.2$ \\
Albumin & $1.30 \pm 0.04$ & $1.32 \pm 0.07$ & $1.14 \pm 0.46$ \\
Total Protein & $2.85 \pm 0.20$ & $3.08 \pm 0.28$ & $2.88 \pm 0.65$ \\
Uric acid & $4.87 \pm 1.53$ & $6.37 \pm 3.54$ & $4.02 \pm 1.29$ \\
Creatinine & $0.03 \pm 0.01$ & $0.03 \pm 0.01$ & $0.03 \pm 0.01$ \\
\hline
\end{tabular}

${ }^{a, b}$ Different superscripts within the same rows indicate significantly different $(\mathrm{P}<0,05)$

T0: chicks rcceiving basal diet without $\mathrm{FF}, \mathrm{T} 1$ : chicks rcceiving basal diet contained 5\% FF, T2 : chicks rcceiving basal diet contained 10\% FF, HDL:high-density lipoprotein,LDL:low-density lipoprotein, SGOT: serum glutamat oksaloasetat transaminase, SGPT: serum glutamat piruvat transaminase 
Table 3. Hematological Parameters of the Chicken Fed Fermented the Used Rice

\begin{tabular}{|c|c|c|c|c|}
\hline Parameters & T0 & & $\mathrm{T} 1$ & $\mathrm{~T} 2$ \\
\hline Leukocytes $\left(10^{2} / \mathrm{mm}^{3}\right)$ & $73.7 \pm 7.64$ & 62.9 & \pm 11.1 & $61.1 \pm 10.2$ \\
\hline Erythrocyte $\left(10^{6} \mathrm{~mm}^{3}\right)$ & $2.88 \pm 0.23$ & 2.88 & \pm 0.28 & $2.72 \pm 0.18$ \\
\hline Haemoglobin(g/dl) & $9.80 \pm 0.84$ & 10.1 & \pm 1.24 & $9.60 \pm 0.82$ \\
\hline Haematocrit(\%) & $38.5 \pm 3.41$ & 35.7 & \pm 3.62 & $33.9 \pm 2.01$ \\
\hline Platelets & $10.8 \pm 2.77$ & 16.0 & \pm 12.14 & $10.0 \pm 1.41$ \\
\hline Lymphocytes (\%) & $71.0 \quad \pm 8.21$ & 59.5 & \pm 10.52 & $57.5 \pm 8.39$ \\
\hline Neutrophils (\%) & $2.70 \pm 1.04$ & 3.40 & \pm 1.82 & $3.60 \pm 1.98$ \\
\hline $\operatorname{MCV}(\mathrm{fl})$ & $134 \pm 3.39^{\mathrm{a}}$ & 124 & $\pm 1.13^{\mathrm{b}}$ & $\pm 0.78^{b}$ \\
\hline $\mathrm{MCH}(\mathrm{pg})$ & $32.0 \pm 4.00$ & 34.3 & \pm 1.53 & $35.2 \pm 2.49$ \\
\hline $\mathrm{MCHC}(\%)$ & $25.4 \pm 0.90^{\mathrm{b}}$ & 27.7 & $\pm 1.27^{\mathrm{a}}$ & $28.2 \pm 1.93^{\mathrm{a}}$ \\
\hline
\end{tabular}

${ }^{a, b}$ Different superscripts within the same rows indicate significantly different $(\mathrm{P}<0,05)$

T0: chicks rcceiving basal diet without FF, T1: chicks rcceiving basal diet contained 5\% FF, T2 : chicks rcceiving basal diet contained 10\% FF,MCV: Mean corpuscular volume, $\mathrm{MCH}$ : Mean corpuscular haemoglobin, MCHC: Mean corpuscular haemoglobin concentration

comsumption of the chickens at 42 days olds (Table 6).

\section{DISCUSSION}

In was shown in this present study that feeding diets containing FF increased the levels of total cholesterol in serum of broilers. The elevated total cholesterol in this study seemed to be attributed to the increased HDL (good cholesterol) levels in the birds provided with the diets containing FF. In line with this, Santoso et al. (2019) previously reported that feeding fermented Sauropus androgynus leaf resulted in increased HDL levels in the blood of broilers. The latter investigators suggested that the presence of polyphenolic compounds in the fermented leaf may be responsible for the increased HDL level. However, this did not occur in our case, as the used rice naturally does not contain a substantial amount of polyphenolic compounds. With regard to the filamentous fungus $C$. crassa as the fermentation starter, such fungus has been reported to possess probiotic effect, which may account for the increased HDL levels in the serum of broilers. Yazhini et al. (2018) suggested that dietary supplementation of probiotic may change the metabolism of lipoprotein resulting in increased HDL cholesterol concentration and, on the other hand, reduced LDL cholesterol in broiler chickens.

In this study, feeding diets containing FF resulted in decreased MCV values of broilers. The reason for such conditions was not exactly known, but it was most probably that the decreased potential of infections may be attributed to the decreased MCV levels in the FF-treated broilers. This inference was supported by the study of Dar et al. (2014) at which Eimeria tenella infection increased the level of MCV (macrocytic anemia) in broiler chickens. Our inference was also supported by the fact that feeding FF decreased the intestinal population of coliform of broilers. The values of MCHC increased with feeding diet containing FF to chickens in this current study. In accordance with our finding, Sugiharto et al. (2020) have recently reported that feeding fermented banana peel resulted in elevated level of MCHC of broilers. The latter authors suggested that fermented feed may enhance the haematopoietic activity in broiler chickens. Other possibilities may that the probiotic activity of the filamentous fungus $C$. crassa used as fermentation starter improved the protein digestibility and thus enhance the protein availability for haematopoietic activity. Note that 
Table 4. The number of Intestinal Microbial Population in Ileum and Caecum of the Chicken Fed Fermented the Used Rice

\begin{tabular}{|c|c|c|c|c|c|c|}
\hline & \multicolumn{2}{|c|}{ T0 } & \multicolumn{2}{|c|}{$\mathrm{T} 1$} & \multicolumn{2}{|c|}{$\mathrm{T} 2$} \\
\hline & E.coli & LAB & E.coli & LAB & E.coli & LAB \\
\hline Ileum & $6.70 \pm 0.78$ & $11.0 \pm 1.05$ & $8.82 \pm 1.51$ & $11.3 \pm 0.37$ & $7.32 \pm 0.13$ & $11.3 \pm 0.51$ \\
\hline Caecum & $9.06 \pm 0.35^{\mathrm{a}}$ & $11.2 \pm 1.13^{b}$ & $8.04 \pm 0.83^{b}$ & $11.9 \pm 0.12^{\mathrm{ab}}$ & $8.71 \pm 0.36^{\mathrm{ab}}$ & $12.0 \pm 0.24^{\mathrm{a}}$ \\
\hline
\end{tabular}

${ }^{a, b}$ Different superscripts within the same rows indicate significantly different $(\mathrm{P}<0,05)$

T0: chicks receiving basal diet without FF, T1: chicks rcceiving basal diet contained 5\% FF, T2 : chicks rcceiving basal diet contained 10\% FF, E.coli : Escherichia coli, LAB : Lactic acid bacteria

Table 5. Internal Organs Weight of Chicken Fed with Fermented the Used Rice

\begin{tabular}{lccc}
\hline \multicolumn{1}{c}{ Organ } & $\mathrm{T} 0$ & $\mathrm{~T} 1$ & $\mathrm{~T} 2$ \\
\hline Heart & $8.12 \pm 0.30^{\mathrm{b}}$ & $8.50 \pm 0.94^{\mathrm{b}}$ & $10.4 \pm 1.68^{\mathrm{a}}$ \\
Liver & $53.3 \pm 4.75$ & $51.1 \pm 5.00$ & $53.0 \pm 7.76$ \\
Proventriculus & $9.73 \pm 1.02$ & $7.10 \pm 0.54$ & $8.67 \pm 1.76$ \\
Gizzard & $31.0 \pm 2.16$ & $32.7 \pm 5.47$ & $33.4 \pm 5.24$ \\
Pancreas & $5.43 \pm 2.16$ & $5.04 \pm 0.65$ & $4.83 \pm 1.28$ \\
Spleen & $1.70 \pm 0.46$ & $1.70 \pm 0.81$ & $1.84 \pm 0.81$ \\
Thymus & $1.79 \pm 0.97$ & $3.00 \pm 0.70$ & $2.23 \pm 0.70$ \\
Bursa of fabricius & $0.68 \pm 0.13$ & $0.71 \pm 0.29$ & $0.87 \pm 0.29$ \\
Duodenum & $10.0 \pm 1.41$ & $11.4 \pm 1.56$ & $9.57 \pm 2.36$ \\
Jejunum & $24.7 \pm 4.75^{\mathrm{a}}$ & $19.8 \pm 3.97^{\mathrm{ab}}$ & $18.4 \pm 3.19 \mathrm{~b}$ \\
Ileum & $17.0 \pm 3.34$ & $18.4 \pm 4.04$ & $15.7 \pm 2.24$ \\
Cecum & $11.4 \pm 3.40$ & $12.7 \pm 4.67$ & $8.02 \pm 2.23$ \\
\hline
\end{tabular}

${ }^{\mathrm{a}, \mathrm{b}}$ Different superscripts within the same rows indicate significantly different $(\mathrm{P}<0,05)$

T0: chicks rcceiving basal diet without $\mathrm{FF}, \mathrm{T} 1$ : chicks rcceiving basal diet contained 5\% FF, T2 : chicks rcceiving basal diet contained $10 \% \mathrm{FF}$

protein is a crucial nutrient needed for red blood cells as well as haemoglobin synthesis (Zanetti et al., 2013).

The present study showed that feeding diet as containing $\mathrm{FF}$ decreased coliform and increased LAB populations in the caecum of broilers. In agreement with this finding, Yudiarti et al. (2012) reported that the addition of $0.5 \%$ dried culture of C.crassa in feed could reduce the number of bacteria and fungi in caecum of the indigenous chicken. The decreased number of coliform seemed due to the probiotic activity of the fungus $C$. crassa. Indeed, C. crassa exhibited antimicrobial activity in the intestine of poultry as reported previously by Yudiarti et al. (2019).

Our present finding showed that chickens fed diet containing 10\% FF had higher relative weight of heart (Table 5). The increased weight of the heart in the current study may due to the enlargement of the heart size, which is usually caused by the 
Table 6. Body Weight Gain, FCR and Feed Consumption of the Chicken Fed with Fermented the Used Rice at 42 Days Olds

\begin{tabular}{lrrr}
\hline \multicolumn{1}{c}{ Parameters } & \multicolumn{1}{c}{ T0 } & \multicolumn{1}{c}{ T1 } & T2 \\
\hline BWG (g/day) & 44.44 & 44.60 & 46.34 \\
FCR & 2.29 & 2.36 & 2.24 \\
Feed comsumption (g/day) & 102.08 & 105.29 & 104.22 \\
\hline
\end{tabular}

T0: chicks rcceiving basal diet without FF, T1: chicks rcceiving basal diet contained $5 \% \mathrm{FF}, \mathrm{T} 2$ : chicks rcceiving basal diet contained $10 \%$ FF, BWG: body-weight gain, FCR: feed conversion ratio

enlargement of cardio-muscular of chickens (Ressang, 1998). The reason for the increased cardio-muscular development was not exactly known, but possibly the increased activity of heart in circulating the blood throughout the body was associated with the increased cardio-muscular development. Note that feeding fermented feed as well as probiotic supplementation may be attributed to the increased nutrient digestibility and hence nutrient available for cellular metabolism (Sugiharto, 2017; Sugiharto and Ranjitkar, 2019). To reach the cells, the nutrients must be circulated, and in this case the heart plays a crucial role in the nutrient circulations.

The present finding showed that broilers fed diets containing $10 \% \mathrm{FF}$ had lower jejunal relative weight when compared to control. Jejunum is the intestinal segment functioning in digesting and absorbing the nutrients. Previous study indicated that feeding fermented feed or probiotic supplementation improved the digestive enzyme activity in broilers, implying the improved digestion and absorption especially in the duodenum (note that digestive enzymes work primarily in the duodenum) (Sugiharto and Ranjitkar, 2019). Owing to this fact, the improved digestion and absorption in the duodenum may implicate in the less nutrients reaching the jejunum and ileum of broilers. The latter condition may therefore reduce the activity of jejunum, which consequently reduced the intestinal muscle development (and thus jejunal weight) of broilers. Yet, our inference should be taken with caution as we did not conduct the digestibility trials and nitrogen retention during the in vivo experiment.

Feeding FF up to $10 \%$ had no effect on the body weight gain (BWG), FCR and feed comsuption of broiler. These findings indicated that the used of FF did not have negative impacts on the production performance of broilers. Furthermore, our results also confirmed that the FF could reduce the proportion of yellow corn as energy-rich feed ingredient for broiler and the important point is as economically this will reduce production costs.

\section{CONCLUSION}

The use of C. crassa-fermented used rice as functional feed ingredient improved the physiological conditions, intestinal bacterial population and had no detrimental effect on growth performance of broiler.

\section{ACKNOWLEDGMENTS}

The study was financially supported by Diponegoro University, Semarang Central Java, Indonesia through non-tax state revenue (PNBP) No. 385-34/UN7.P4.3 /PP/2018, 17 May 2019.

\section{REFERENCES}

Cencic, A. and W. Chingwaru. 2010. Review of The Role of functional foods, nutraceuticals, and food supplements in intestinal health. Nutrients. 2:611-625.

Dar, S.A., M. Ashfaque, I. A. Mir, P. Verma and A. A. Zargar. 2014. Effect of garlic extract on haematobiochemical changes in Eimeria tenella infected broiler chicken. Natl. Acad. Sci. Lett. 37(4):311-316.

Ressang, A. A. 1998. Patologi Khusus Veteriner. Gadjah Mada Press. Yogyakarta.

Santoso, U., Y. Fenita and Kususiyah. 2019.The usefulness of fermented katuk (Sauropus 
androgynus) plus bay leaves to modify fat accumulation, cholesterol and chemical composition of broiler meat. J. Indonesian Trop. Anim. Agric. 44 (1): 84-95.

Sugiharto, S., T. Yudiarti, I. Isroli, E. Widiastuti and F. Dwi Putra. 2017. Effect of dietary supplementation with Rhizopus oryzae or Chrysonilia crassa on growth performance, blood profile, intestinal microbial population, and carcass traits in broilers exposed to heat stress. Arch. Anim. Breed. 60: 347-356.

Sugiharto, S.,T.Yudiarti,I.Isroli and E.Widiastuti. 2018. The potential of tropical agro industrial by product as a functional feed for poultry.Iranian.J.of Appl.Anim.Sci. 8(3): 375-385.

Sugiharto, S. and S. Ranjitkar. 2019. Recent advances in fermented feeds towards improved broiler chicken performance, gastrointestinal tract microecology and immune responses: A Review. Animal Nutrition. 5: 1-10.

Sugiharto, S., T. Yudiarti, I. Isroli, E. Widiastuti, H.I.Wahyuni and T.A.Sartono.2020. Growth performance, haematological responses, intestinal microbiology and carcass traits of broiler chickens fed finisher diets containing two-stage fermented banana peel meal. J. Trop Anim Health and Production. 52: 1425-1433.

Yazhini, P., P. Visha, P. Selvaraj, P.
Vasanthakumar and V. Chandran. 2018. Dietary encapsulated probiotic effect on broiler serum biochemical parameters. Veterinary World.11(9):1344-1348.

Yudiarti, T., V.Yunianto, B.I., R. Murwani, E. Kusdiyantini. 2012. The effect of Chrysonilia crassa additive on duodenal \& caecal morphology bacterial \& fungal number and productivity of ayam kampung. Int. J. Sci. Eng.3:26-29.

Yudiarti, T., S. Sugiharto, I. Isroli, E. Widiastuti, H. I.Wahyuni and T. S. Sartono. 2019. Effect of fermentation using Chrysonillia crassa and Monascus purpureuson nutritional quality, antioxidant, and antimicrobial activities of used rice as a poultry feed ingredient. J. Adv. Vet. Anim. Res. 6(2): 168-173.

Yudiarti, T., I Isroli and V. D. Yunianto. 2020. Nutritive and antioxidative properties of some selected agroindustrial by-products fermented with the fungus Chrysonillia crassa as alternative feedstuffs for poultry.J. of Physics: Conf. Series. 1524. 012145 IOP Publishing.

Zanetti, E., A. Masi, M. Pivato, S. Tolin, A. R. Trentin, C. Guler, S.Yalçin and M. Cassandro. 2013. A note on protein expression changes in chicken breast muscle in response to time in transit before slaughtering. Proteome Sci.11: 34.1-10. 